\title{
Fra lige til ulige sikkerhed i Europa
}

Af Mette Skak

Visionen om lige sikkerhed begyndte som et anliggende på individniveau under henvisning til menneskerettighederne, men er som følge af afkoloniseringen af det sovjetiske imperium blevet til et spørgsmål om lige sikkerhed for stater. Et af de store problemer er, at de postkommunistiske OSCE-deltagere har vidt forskellige forudsætninger for selv at tage vare på deres sikkerhed, og et endnu større problem for europæisk sikkerhed er Ruslands manglende respekt for folkerettens princip om, at man gør de grænser, der før var indre forvaltningsgrænser til internationale grænser, uanset hvor tilfældige og urimelige de måtte forekomme.

Med Ruslands annektering af Krimhalvøen og hele den uerklærede krig mod Ukraine blev ikke bare det såkaldte Budapest-memorandum af 1994, der gav Ukraine sikkerhedsgarantier, men også Helsinki-slutakten fra 1975 kuldkastet. Alligevel blev dette års rubinbryllup for denne milepæl i det sovjetiske koldkrigsdiplomati forbigået i tavshed i det ellers så Sovjetnostalgiske Rusland.

Rusland gør ellers klogt i at kopiere den fornyelse af samfundene indefra, der gav Vesten soft power til efterfølgende at sejre i den kolde krig som følgevirkning af Helsinki-aftalerne, mener den russiske analytiker Fjodor Lukjanov ('How Russia Can Learn From Helsinki') Moscow Times, 20. August, 2015).

Så lad os kaste blikket tilbage til Helsinki-slutakten som et søm i Sovjetunionens ligkiste og ligeledes se nærmere på Budapest-memorandummet som det søm i Ukraines ligkiste, det viste sig at være. Jeg læner mig her op ad den amerikanske sikkerhedspolitiske veteran David S. Yost ('The Budapest Memorandum and Russia's intervention in Ukraine', International Affairs, Vol. 91, No. 3, 2015, ss. 505-538). Ifølge ham tegner Ruslands forfølgelse af sine kortsigtede interesser i Ukraine til at blive en milepæl i kuldkastelsen af den internationale orden, og den truer direkte ikke-spredningen af atomvåben. Ruslands kyniske udnyttelse af fraværet af atomar afskrækkelse for Ukraines vedkommende kan kun bekræfte slyngelstater som Nordkorea og Islamisk Stat i, at man skal sørge for selv at have bomben.

Mere om Budapest-memorandummet senere.

Mette Skak, cand. mag. i russisk sprog og historie og ph.d. i statskundskab, er lektor ved Institut for Statskundskab, Aarhus Universitet. Hun har adskillige gange besøgt Rusland som led i sin forskning, og hun er forfatter til utallige artikler og flere bøger. 


\section{Helsinki-slutakten}

Hvad Helsinki-slutakten angår, må man sige, at den var en diplomatisk genistreg $i$ klasse med George Kennans containment, Marshall-planen og Ronald Reagans senere stjernekrig. Men da heltene bag de 35 underskriver-nationer var støvede diplomater, som vel dårligt nok anede, hvordan de djævelske detaljer ville udmøntes i praksis, har de aldrig fået Nobels fredspris, som det egentlig tilkom dem.

Helsinki-slutakten forblev en forbløffende underspillet triumf for vestlig liberal værdipolitik, som ingen gider bruge krudt på i fagene historie, samfundsfag og international politik.

Det forunderlige var, at den allermest ivrige part i forhandlingerne var den sovjetiske leder Leonid Bresjnev, der satte hele sin personlige prestige på højkant. Som Erling Bjøl ville sige, var det snedige ved Vestens svar på Bresjnevs initiativ, at det herved lykkedes at camouflere en sejr som nærmest et nederlag.

Sagen er, at der i Sovjetunionen i tiden omkring underskrivelsen af slutakten i sommeren 1975 herskede selvfedme en selvfedme næret af adskillige sejre i de stedfortræderkrige i den tredje verden, der prægede den kolde krigs slutfase. Blandt andet som følge af støtte fra Sovjetunionen lykkedes det diverse venstreorienterede befrielsesbevægelser at få kolonimagten Portugal til at afhænde Angola, Mozambique og Guinea-Bissau.

Hertil kom USA's tilbagetrækning fra Vietnam, der gjorde det Kina-skeptiske Vietnam til en sovjetisk satellit på linje med Cuba.

Derfor mente Bresjnev det alvorligt, når han på det sovjetiske kommunistpartis 25. partikongres i 1976 erklærede, at styrkeforholdet nu var tippet over i socialismens, dvs. Sovjetunionens favør.
Samtidig var Brezjnevs egne velmagtsdage ovre - ved selve underskrivelsesceremonien i Helsinki var han nærmest i koma og formåede dårligt nok at føre pennen til underskrift - så han begyndte at tænke på sit eftermæle. Som mærkesag valgte han at arbejde for en formel anerkendelse af Øst-Vest-delingen i Europa gennem vestmagternes accept af det jerntæppe, som den Røde Hær og Stalins politiske håndlangere trak ned gennem Europa, da Anden Verdenskrig klingede af.

Den såkaldte første kurv i Helsinki-aftalerne rummede derfor alle underskriver-nationers anerkendelse af de statslige grænser i Europa som urokkelige. Dvs. med mindre der var tale om en fredelig grænseændring, thi således fik medunderskriveren USA en kattelem ind, der pegede frem mod samlingen af Tyskland efter Murens fald.

Til beroligelse for Sovjetunionen bøjede den amerikanske præsident George Bush senior det i neon, at USA anser den nuværende Oder-Neisse-grænse mellem Polen og Tyskland for gyldig - netop under henvisning til Helsinki-Slutakten, der fastfryser Europas grænser, som de fremstod i 1945. Tilsammen sikrede det en fredelig samling af Tyskland og et sjældent harmonisk forhold mellem arvefjenderne Polen og Tyskland, som alle nyder godt af. Mere indirekte har Helsinki-ånden sikret, at ingen stiller spørgsmålstegn ved Kaliningrads status som en sovjetisk eksklave, der nu hører under Rusland. Alt andet ville være uklogt.

Bresjnev var ikke blind for, at den var gal med Sovjetunionens økonomiske formåen. På et møde med sine østeuropæiske vasaller i foråret 1975 parerede han deres ønsker om økonomisk hjælp ved at sige, at han desværre kom "med tomme lommer (...) Vi er nødt til ærligt at ved- 
gå, at vi står over for vanskelige problemer (...) Vi må tænke alvorligt over, hvordan vi gør vores økonomi mere rentabel.” Som påpeget af sovjetologen Stephen Kotkin blev Sovjetunionen teknologisk sejlet fuldstændig agterud af den anderledes menneskelige vestlige efterkrigskapitalisme. Det gav kommunismen alvorlige problemer med legitimiteten i dens egne befolkningers øjne. Folk stod i kø efter dagligdags forbrugsvarer, boligerne var elendige; kun oprustningen var i top. Følgelig blev det Bresjnevs mærkesag nummer to at styrke importen af teknologi og andre nødvendige varer, hvilket kom til at udgøre den såkaldte anden kurv i Helsinki-aftalerne.

\section{Den tredje kurv}

Men så var der den tredje kurv, vestmagternes betingelse for at gå ind på Bresjnevs ønsker. Den forpligtede Sovjetunionen og dens lydstater på menneskerettighederne, på fri bevægelighed og udveksling af ideer. På det punkt var der hårde forhandlinger, man måtte kæmpe fra ord til ord i de forudgående år, før man fik aftaleteksten på plads.

Den sovjetiske udenrigsminister Andrej Gromyko nøjedes med at sikre sig Bresjnevs tilsagn, når det ind imellem mislykkedes at nå hele Politbureauet rundt i det dynamiske forhandlingsforløb. Men da indholdet i den tredje kurv blev fremlagt for høgene derhjemme - Suslov, Podgornyj, Kosygin og Andropov, - mente de, at Gromyko havde åbnet en ladeport for indblanding i det indre politiske liv i Sovjetunionen. Gromyko forsvarede sig med, at anerkendelsen af efterkrigstidens grænser og det gældende politiske landkort i Europa længe havde været en sovjetisk mærkesag, aftalen var en propagandasejr uden lige; oven i købet ville den anden kurv mu- liggøre økonomisk genopretning gennem blomstrende samhandel med Vesten.

I årene før underskrivelsen af aftalekomplekset stødte Bresjnev på en lignende modstand hos den konservative, men lige så økonomisk trængte østtyske partichef Erich Honecker. Han fik gennemtrumfet sin mærkesag, den diplomatiske anerkendelse af DDR, selv om Bresjnev hyklerisk kritiserede ham for at være i lommen på Forbundsrepublikken og have blottet sig for farlig indflydelse som følge af de 8 mio. besøgende fra Vesttyskland i 1974. Det stærke østtyske hemmelige politi Stasi sørgede for, at Bresjnev vidste alt om det østtyske diplomati.

Såvel Bresjnev som Honecker havde imidlertid en tyrkertro på efterretningstjenestens greb om tingene og troede derudover på den afgrænsende effekt af de opvoksende generationers DDR-horisont (Vladimir Bilandzic, Dittmar Dahlmann \& Kosanovic: From Helsinki to Belgrade, 2012: 228). Kort sagt en tyrkertro på hårde magtformer som missiler og undertrykkelse parret med foragt for Vestens subtile bløde magt, der ikke lå i hænderne på statsapparatet, men på civilsamfundet: The Beatles, ungdomsoprøret og anden empowerment.

Gromyko bagatelliserede den tredje kurv: 'Vi er herrer i eget hus!' Denne besværgelse beroligede høgene omkring ham, så det sovjetiske partiblad Pravda offentliggjorde intetanende Helsinki-aftalernes fulde ordlyd.

Ovre i USA, der hele vejen igennem lå underdrejet i forhandlingerne, fangede man heller ikke hvilken murbrækker vesteuropæerne her stod med $\mathrm{i}$ hånden, da den ikke synligt hamrede løs på Berlin-muren. Førnævnte Kennan, der jo ellers vidste et $\mathrm{og}$ andet om hvordan man skulle tackle Sovjetunionen, afskrev Helsinki-aftalerne 
som 'a lot of nonsense', der ikke forpligtede nogen. Han havde mere fidus til Henry Kissinger og den igangværende amerikansk-sovjetiske afspænding.

Men den hårdt trængte politiske opposition i Sovjetunionen og Østeuropa greb aftaleteksten med kyshånd, idet der opstod Helsinki-grupper i Moskva, Ukraine og Tjekkoslovakiet. Folk som Jurij Orlov, Kronid Ljubarskij, Dina Kaminskaja og Ljudmila Aleksejeva forlangte, at Sovjetunionen nu overholdt menneskerettighederne. Aleksejeva sagde på vegne af Moskva-gruppen:

"Hvad vil der ske, hvis borgerne handler ud fra antagelsen om, at de har rettigheder? Hvis en person gør det, bliver han en martyr; hvis to gør det, bliver de kaldt en fjendtlig organisation. Men hvis tusinder gør det, bliver staten nødt til at moderere sin adfærd."

Ukraines Helsinki-gruppe talte efterhånden prominente dissidenter som Leonid Pljushch, der sammen med esteren Mart Niklus og litaueren Viktoras Petkus, begge politiske fanger, erklærede sig som medlemmer. Der opstod Helsinki-grupper i andre Sovjetrepublikker - Litauen, Georgien og Armenien.

\section{KGB til modangreb}

De sovjetiske myndigheder, dvs. KGB gik til modangreb og havde i 1981 arresteret eller udvist de fleste medlemmer af Moskvas gruppe af Helsinki-overvågere. Men chefen for KGB, Jurij Andropov, havde det problem, at den verdenskendte dissident Andrej Sakharov blev koblet sammen med Helsinki-aftalerne, da han i oktober 1975 blev indstillet til Nobels Fredspris.

Derfor fik KGB-afdelingen i Oslo ordre på at stikke en kæp i hjulet. Da det ikke lykkedes, tog Andropov personligt affære og søsatte en aggressiv misinformations- kampagne. Den rettede sig blandt andet mod Danmark, fordi København lagde for med de første Sakharov-høringer om menneskeretskrænkelser i Sovjetunionen (The Mitrokhin Archive, 2000: 420 ff.). I øvrigt var der dannet Helsinki-grupper i de jugoslaviske delstater samt i Tjekkoslovakiet. Denne blev kendt som Charta 77 og talte Vaclav Havel samt Zdenek Mlynar, en veteran fra Prag-foråret i 1968. Også her gik myndighederne til modangreb: Flere Charta 77-aktivister blev tvunget til at samarbejde med det tjekkoslovakiske hemmelige politik, det berygtede StB.

De kommunistiske myndigheders ofte desperate modtræk udstillede deres himmelråbende mangel på legitimitet. Andropov fandt på at fabrikere tætte forbindelser mellem Sakharov og dels Chiles forhadte diktator Pinochet, dels CIA som sponsor bag Sakharov-høringerne, dels zionismen. Arrestere ham turde Andropov imidlertid ikke, i stedet anbragte han Sakharov og hans kone i indre eksil i den forbudte by Gorkij, hvor de sad, indtil Gorbatjov ophævede deres forvisning sidst i 1986.

KGB-forskningen er således enig med forskningen i Helsinki-aftalerne i, at Sovjetunionen begik en strategisk brøler med Helsinki-aftalerne: De banede vejen for det politiske jordskælv med Murens fald (Thomas Risse, Stephen C. Rapp, Kathryn Sikkink: The Power of Human Rights, 1999: 205-233). Efterspillet i denne såkaldte CSCE-proces blev Paris-Charteret For et Nyt Europa fra 1990, der erklærede delingen af Europa for ophørt til fordel for demokrati, menneskerettigheder, fred og enhed. Charteret stadfæstede på ny de 10 principper fra Helsinki-slutakten. Ingen mislyde, kun jubel over, at den kolde krig var slut. 


\section{Indbygget dilemma}

CSCE står for Konferencen for Sikkerhed og Samarbejde i Europa. Den blev på topmødet i Budapest i 1994 til den internationale organisation, som vi i dag kender som OSCE. På det tidspunkt var der imidlertid gnidninger mellem Rusland og Vesten, idet den daværende russiske præsident Boris Jeltsin mente, at fordrageligheden mellem Øst og Vest var afløst af 'kold fred'. Det, der nagede ham, var tilnærmelsen mellem NATO og det postkommunistiske Østeuropa. Jeltsin valgte som alle andre russere at se bort fra, at tilnærmelsen ikke var NATOs, men østeuropæernes initiativ, der skyldtes chokket over myrderierne i det tidligere Jugoslavien.

Det var gamle Helsinki-kendinge som Havel, der førte an i kurmageriet over for NATO, som alliancen forholdt sig særdeles tøvende til; så meget, at balterne følte, at sikkerheden i Europa var ulige fordelt.

Med andre ord er det indbyggede dilemma bag Helsinki-aftalerne at efterleve idealet om lige sikkerhed for ulige nationer, hvad angår størrelse, militær slagkraft og geopolitisk placering. Den russiske holdning til den sag fremstår mere og mere utvetydigt som stormagtens sikkerhedspolitiske særrettigheder. Det ses af Putins bagatelliserende udtalelser om Molotov-Ribbentrop-aftalerne af 1939 som blot 'den tids diplomati'.

De oprindelige Helsinki-underskrivere var en uskøn blanding af bødler og ofre for den kolde krig, stormagter og småstater, så det overraskende er selve loyaliteten over for aftale-komplekset. Faktisk overlevede Helsinki-aftalerne Sovjetunionens sammenbrud i 1991, idet man blot udvidede kredsen af medlemsnationer på 35 med 14 ekstra, idet Rusland overtog Sovjetunionens sæde. For tiden tæller OSCE
57 deltagere og rækker langt ind i Centralasien, ja helt til Mongoliet, hvortil kommer de nu selvstændige jugoslaviske delstater, Tjekkiet, Slovakiet og Albanien.

Visionen om lige sikkerhed begyndte således som et anliggende på individniveau under henvisning til menneskerettighederne, men er som af følge afkoloniseringen af det sovjetiske imperium blevet til et spørgsmål om lige sikkerhed for stater. Et af de store problemer er, at de postkommunistiske OSCE-deltagere har vidt forskellige forudsætninger for selv at tage vare på deres sikkerhed, fx er de centralasiatiske stater skaller uden meget andet indhold end regimets vilje til at berige sig selv og holde kritikere nede. Et endnu større problem for europæisk sikkerhed er Ruslands manglende respekt for folkerettens 'princip uti possidetis iuris' som rettesnor i afkoloniseringer. Det latinske fagudtryk betyder, at man gør de grænser, der før var indre forvaltningsgrænser til internationale grænser uanset hvor tilfældige og urimelige, de måtte forekomme. Skoleeksemplet er de grænser, de europæiske kolonimagter trak med en lineal i Afrika, som alle holder fast i af skræk for alternativet.

\section{Budapest-memorandummet}

Overført på den aktuelle konflikt mellem Rusland og Ukraine betyder princippet, at uanset om russerne i dag er vrede over Khrusjtjovs overdragelse af Krim-halvøren til Ukraine 1954, ja så fanger bordet.

Det bringer os frem til Budapest-memorandummet, der kom i stand i marginen på førnævnte CSCE-topmøde i 1994 - igen som en mærkesag for ikke mindst Moskva. Men da Ukraine på det tidspunkt sad inde med klodens tredjestørste beholdning af atomvåben var de to andre medunderskrivere, USA og Storbritanni- 
en, lige så forhippede på aftalen. Den gik nemlig ud på, at ukrainerne (ligesom hviderusserne og kasakkerne) gav afkald på de sovjetiske atomvåben, de havde på deres territorium.

Til gengæld for det gav Budapest-memorandummet dem garantier fra Rusland for deres statslige grænsers ukrænkelighed, mens de to vestlige stormagter agerede 'vitterlighedsvidner'. Aftalen byggede på Helsinki-aftalerne og forpligtede i øvrigt Rusland til ikke at øve økonomisk pression mod Ukraine (hvem sagde gaskrige?).

Rusland benægter sit aftalebrud under henvisning til, at Ukraines regering blev udskiftet i februar 2014. Men som påpeget af Yost er det ikke regeringer, der på egne vegne indgår aftaler, de gør det på vegne af staten. Derfor gælder folkerettens helt overordnede princip pacta sunt servanda - indgåede pagter skal overholdes.

Ruslands væbnede intervention i Ukraine har skabt en ny frossen konflikt i Europas baghave og er blevet fulgt op med truende russisk adfærd mod NATO, ikke mindst mod de baltiske småstater. Rusland synes beruset af sin genfundne vilje til konfrontation med omverdenen, som unægtelig giver opbakning til Putin som landets leder.

Men russerne glemmer, at yderligere spredning af atomvåben truer Ruslands egen sikkerhed, påpeger Yost. Ruslands åbenlyse tilsidesættelse af folkeretten med annekteringen af Krim og krænkelse af Budapest-memorandummet udgør en farlig revisionisme slutter han.

\section{Hvad kan Vesten gøre?}

Og hvad skal omverdenen så gøre ved det? Ja, umiddelbart forekommer situationen i Ukraine meget fastlåst, om end den faktiske neddrosling af kamphandlinger- ne kan tages som udtryk for, at de vestlige $ø$ konomiske sanktioner ikke er uden virkning trods den megen kritik heraf. Realiteten er jo - som ovenfor antydet - at det er mere eller mindre umuligt at garantere lige sikkerhed for alle, det længste man kan komme er at prøve at afhjælpe nogle af de svage parters.

At optage Ukraine i Nato er udelukket, men mindre kan gøre det såsom hjælp til at få landet økonomisk på fode og styrke kampen mod korruption. En målsætning om at gøre Ukraine til medlem af OECD - de højtudviklede nationers organisation, der holder et vågent øje med sine medlemmernes økonomiske sundhed - kunne være et fint kompas for landets ledelse at styre efter. En optagelse i OECD ville lokke de internationale investorer til, altså en guldrandet vision.

For selv om det ud fra ovenstående lyder som et spørgsmål om bare at gentage successen med Helsinki-aftalerne er sandheden snarere, at det var en engangsforestilling, som vi skal være taknemmelige for overhovedet kom i stand. Helsinki-gennembruddet nød godt af, at Bresjnev vidste, at han skulle til at takke af, og i øvrigt var han langt fra at være den snu ræv, som Putin er.

Dermed være ikke sagt, at Putin ikke hen ad vejen kan blive tvunget til at tage skeen $\mathrm{i}$ den anden hånd, men mange ting er fundamentalt anderledes i den nuværende internationale situation. Den vigtigste forskel er den overordnede spredning af magten væk fra de etablerede vestlige industrinationer til fordel for de mange oversøiske vækstøkonomier med Indien og Kina som de mest slagkraftige udfordrere. Putin har overfladisk set gjort sig til en del af deres storpolitiske dynamik gennem Ruslands deltagelse i den såkaldte BRIKS-koncert, der også tæller Brasi- 
lien og Sydafrika. BRIKS har indtil videre reageret opportunistisk på Putins grove krænkelser af folkeretten ved at holde hånden over Rusland.

Det er muligt, at gruppens indre modsætninger og de enorme indenrigspolitiske problemer, som hver og en af BRIKS-nationerne kæmper med, med tiden gør det umuligt at holde liv i samarbejdet. Det ville give omverdenen andre kort på hånden over for Rusland. Men som tingene tegner nu må man væbne sig med tålmodighed og afvente, hvordan Ruslands seneste væbnede indgriben, den i Syrien, spænder af.
EU og USA bør på den ene side opretholde de økonomiske sanktioner mod Rusland, stå fast på demokratiernes militære alliance NATO og forsvare svage NATO-allierede. På den anden side bør man følge udviklingen i og omkring Rusland nøje, blandt andet fordi man ikke kan udelukke en udvikling til noget meget værre. Men overordnet gælder det, at ligesom Sovjetunionen viste sig at have begrænset holdbarhed som politisk system, så gælder det samme for det autoritære system, som Putin har opbygget omkring sig selv under varebetegnelsen det suveræne demokrati. 